\title{
MORPHOMETRY OF SACRAL HIATUS AND ITS CLINICAL RELEVANCE IN CAUDAL EPIDURAL BLOCK
}

\author{
KAMAL AHMM ${ }^{1}$, ARA $\mathrm{S}^{2}$, ASHRAFUZZAMAN M ${ }^{3}$, KHATUN $^{4}$, ISLAM MS ${ }^{5}$
}

\begin{abstract}
Context: The variation in anatomical features of sacral hiatus and the dorsal wall of sacral canal is related to its clinical application in caudal epidural anesthesia. Through the sacral hiatus, it is employed in operation in the anal region and on the external genital organs, as well as cystoscopic examination of male. Continuous caudal anesthesia is also used in obstetrics during parturition for better cervical dilatation and shortening the first stage of labor.

Methods: The present study was performed on 172 (one hundred seventy two) adult human dry sacra of unknown sex. The study samples were distributed in male and female sex groups by discriminant function analysis. The study was cross sectional analytical type and was conducted in the department of Anatomy, Dhaka Medical College, Dhaka, from January 2011 to December 2011. The various landmarks of sacral hiatus were measured with the help of digital slide calipers.

Results: The mean length of sacral hiatus in male and female was found $26.38 \pm 12.02 \mathrm{~mm}$ and $25.63 \pm 10.46 \mathrm{~mm}$ respectively. The mean anterior-posterior diameter of sacral hiatus at the apex was found $4.76 \pm 1.73 \mathrm{~mm}$ in male and $4.92 \pm 2.13 \mathrm{~mm}$ in female. Transverse width of the sacral hiatus at the base found $17.29 \pm 3.89 \mathrm{~mm}$ in male and $18.01 \pm 3.70 \mathrm{~mm}$ in female. Different in shape of sacral hiatus between male and female found statistically not significant. Location of apex of sacral hiatus was found highest in number at the level of $4^{\text {th }}$ sacral vertebra (60.20\%) and maximum location of base of the sacral hiatus was at the level of $5^{\text {th }}$ sacral vertebra (91.20\%). The sacral hiatus has anatomical variations and understanding of these variations may improve the success of caudal epidural anesthesia.
\end{abstract}

Key words : Sacral hiatus, apex, caudal epidural anesthesia.

J Dhaka Med Coll. 2014; 23(1) : 31-36.

\section{Introduction}

The sacrum is a large, triangular fusion of five vertebrae, wedged between the two hip (innominate) bones. Its blunted, caudal apex articulates with the coccyx and its superior, wide base with the fifth lumbar vertebra at the lumbosacral angle ${ }^{1}$. The opening present at the caudal end of sacral canal is known as sacral hiatus. It is formed due to the failure of fusion of laminae of the fifth (occasionally 4th) sacral vertebra. It is located inferior to the 4th (or 3rd) fused sacral spines or lower end of median sacral crest. On the surface the hiatus lies about two inches above the tip of coccyx beneath the skin of natal $\mathrm{cleft}^{2}$. The sacral hiatus contains lower sacral and coccygeal nerve roots, filum terminale externa and fibrofatty tissue. In recent state the hiatus is covered by superficial posterior sacrococcygeal ligament which is attached to the margins of the hiatus and the deep posterior sacro-coccygeal ligament attached to the floor of sacral hiatus ${ }^{3}$. The sacral hiatus is palpated as a distinct depression in the midline about $4 \mathrm{~cm}$ above the tip of the coccyx in the upper part of the cleft between the buttocks. The hiatus is bounded laterally by the sacral cornua ${ }^{4}$. Sacral hiatus has been utilized for administration of epidural anesthesia in obstetrics ${ }^{5}$ as well as in orthopedic practice for treatment and diagnosis ${ }^{6}$. The reliability and success of

1. Dr. A. H. M. Mostafa Kamal, Assistant Professor, Department of Anatomy. Dhaka Medical College, Dhaka

2. Dr. Shamim Ara, Professor and Head, Department of Anatomy, Dhaka Medical College, Dhaka.

3. Dr. Md. Ashrafuzzaman, Professor, Department of Anatomy, Chittagong Medical College, Chittagong.

4. Dr. Khadeza Khatun, Lecturer, Department of Microbiology, Dhaka Medical College, Dhaka.

5. Dr. Mohammad Shaiful Islam, Medical Officer, Medicine OPD, Dhaka Medical College Hospital, Dhaka.

For Correspondence : Dr. AHM Mostafa Kamal, Assistant Professor, Department of Anatomy, Dhaka Medical College, Dhaka, Cell Phone: +8801718133080, E-mail: abuhmmk@yahoo.com 
caudal epidural anesthesia depends upon anatomical variations of sacral hiatus as observed by various authors ${ }^{3}$. Single bony landmark may not help in locating sacral hiatus because of anatomical variations. In case of sacralization of coccygeal vertebra it will be difficult to mark the landmark for caudal epidural block ${ }^{7}$. Depth of hiatus less than $3 \mathrm{~mm}$ may be one of the causes for failure of needle insertion. Surrounding bony irregularities, different shapes of hiatus and defects in dorsal wall of sacral canal should be taken into consideration before undertaking caudal epidural block so as to avoid its failure ${ }^{8}$.

\section{Methods:}

A total of 172 (one hundred seventy two) dried completely ossified, grossly normal adult human sacra of unknown sex was assessed. The sacra were collected from Department of Anatomy of Dhaka Medical College, Sir Salimullah Medical College and Shaheed Suhrawardy Medical College, Bangladesh Medical College, Medical College for Women and Hospital, Ibrahim Medical College and M H Somorita Medical College, Dhaka. For this study adult sacra of both sexes were included. The study samples were distributed in male and female sex groups by discriminant function analysis. Each sacrum was studied for different features of sacral hiatus with regards to shape of hiatus, level of base and apex of hiatus, length of hiatus, anteroposterior diameter of sacral hiatus at the apex and transverse width of sacral hiatus at the base. The measurements were taken with the help of digital slide calipers. This study was approved by the Ethical Review Committee of Dhaka Medical College, Dhaka.

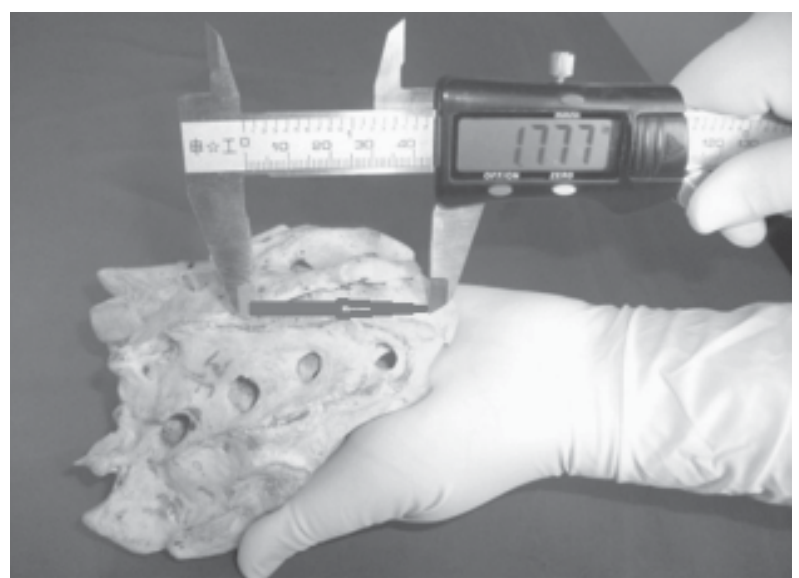

Fig-1: Photograph showing the measurement oflength of the sacral hiatus by using digital slide calipers.

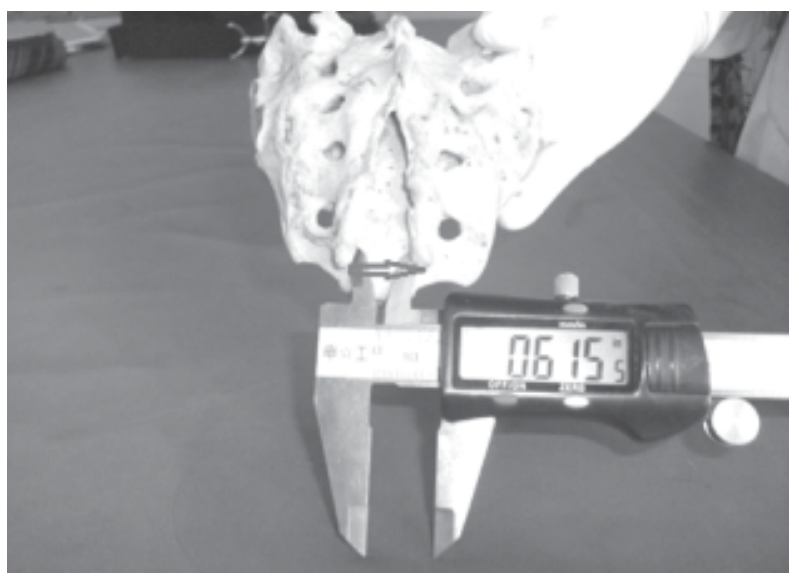

Fig-2: Photograph showing the measurement of the transverse wide of the sacral hiatus at the base by using digital slide calipers.

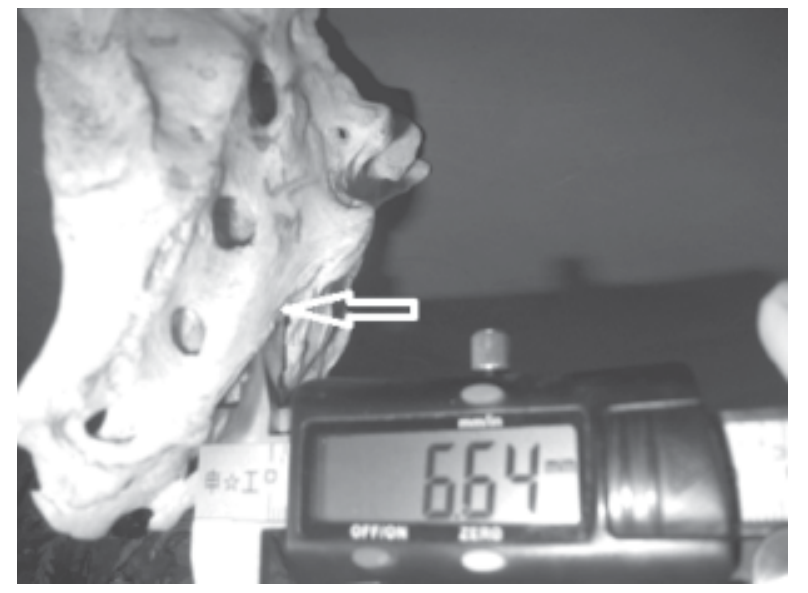

Fig-3: Photograph showing the measurement of anteroposterior diameter of sacral hiatus at the apex by using digital slide calipers.

\section{Results :}

The mean length of sacral hiatus (Table-1; Fig: 4) in male and female was found $26.38 \pm 12.02 \mathrm{~mm}$ and $25.63 \pm 10.46 \mathrm{~mm}$ respectively. Length of sacral hiatus was found greater in male than female and it was statistically significant $(\mathrm{P}<0.001)$. The mean anterior-posterior diameter of sacral hiatus at the apex found $4.76 \pm 1.73 \mathrm{~mm}$ in male and $4.92 \pm 2.13 \mathrm{~mm}$ in female. Transverse width of the sacral hiatus at the base found $17.29 \pm 3.89$ $\mathrm{mm}$ in male and $18.01 \pm 3.70 \mathrm{~mm}$ in female. In both the measurement anterior-posterior diameter of sacral hiatus at the apex and transverse width of the sacral hiatus at the base found greater in female than male and it 
Table -I

Length, anterior-posterior diameter at the apex and transverse diameter at the base of sacral hiatus in male and female

\begin{tabular}{lccc}
\hline Sex & \multicolumn{3}{c}{ Measurement in mm } \\
\cline { 2 - 4 } & $\begin{array}{c}\text { Length of } \\
\text { sacral } \\
\text { hiatus } \\
\text { Mean } \pm \text { SD }\end{array}$ & $\begin{array}{c}\text { Anterior-posterior } \\
\text { diameter of sacral } \\
\text { hiatus at the apex } \\
\text { Mean } \pm \text { SD }\end{array}$ & $\begin{array}{c}\text { Transverse width of } \\
\text { sacral hiatus at the } \\
\text { base } \\
\text { Mean } \pm \text { SD }\end{array}$ \\
\hline Male & $26.38 \pm 12.02$ & $4.76 \pm 1.73$ & $17.29 \pm 3.89$ \\
$(\mathrm{n}=91)$ & $(7.91-57.31)$ & $(1.50-8.57)$ & $(7.11-25.01)$ \\
Female & $25.63 \pm 10.46$ & $4.92 \pm 2.13$ & $18.01 \pm 3.70$ \\
$(\mathrm{n}=80)$ & $(7.47-46.11)$ & $(0.18-13.39)$ & $(2.00-24.49)$ \\
Pvalue & $<0.001^{* * *}$ & $<0.001^{* * *}$ & $<0.001^{* * *}$ \\
Total & $26.02 \pm 11.28$ & $4.83 \pm 1.92$ & $17.62 \pm 3.80$ \\
$(\mathrm{n}=171)$ & $(7.47-57.31)$ & $(0.18-13.39)$ & $(2.00-25.01)$ \\
\hline
\end{tabular}

Figure in parentheses indicate range. Comparison between sex done by student's ' $\mathrm{t}$ ' test, * ${ }^{* *} /{ }^{* * *}=$ significant.

was statistically significant $(\mathrm{P}<0.001)$. Regarding shape of the sacral hiatus (Table-II; Fig: 5,6$)$, inverted U shaped was $38.86 \%$ and $37.05 \%$, inverted $\mathrm{V}$ shaped was $32.25 \%$ and $38.27 \%$, irregular shaped was $16.68 \%$ and $13.57 \%$, elongated shaped was $6.66 \%$ and 4.94\%, dumbbell shaped was $5.55 \%$ and $4.94 \%$

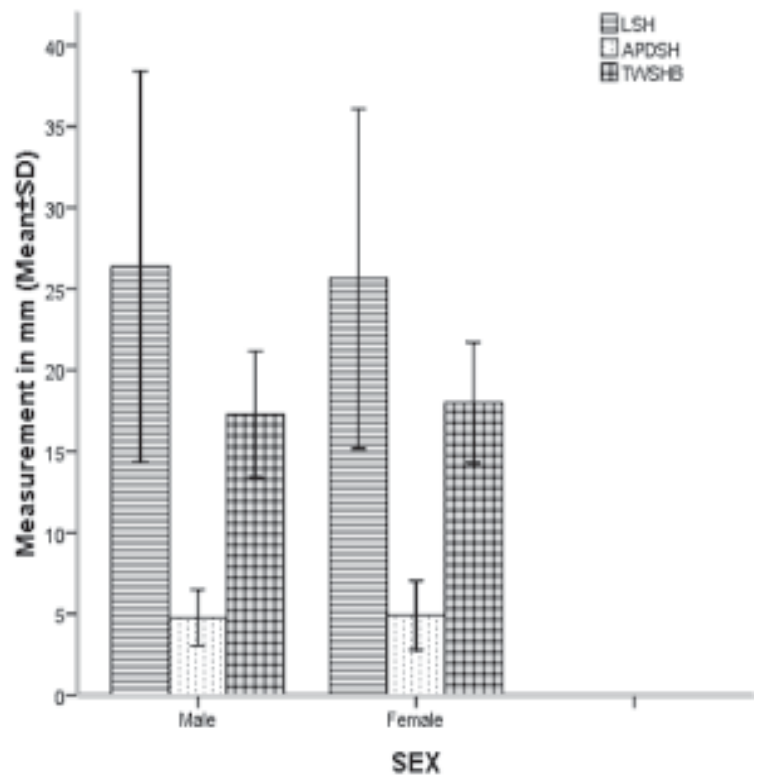

Fig-4 : Bar diagram showing length (LSH), anterior-posterior diameter at the apex (APDSH) and transverse width at the base (TWSHB) of sacral hiatus in male and female. and bifid shaped was $0.0 \%$ and $0.60 \%$ in male and female respectively. Different in shape of sacral hiatus between male and female found statistically not significant. Location of apex (Table-III; Fig: 7) of sacral hiatus was found highest in number at the level of $4^{\text {th }}$ sacral vertebra $(60.20 \%)$ and lowest in number at the level of $2^{\text {nd }}$ and $5^{\text {th }}$ sacral vertebra $(4.70 \%)$. Position of the apex of sacral hiatus at the level of $3^{\text {rd }}$ sacral vertebra was found $30.40 \%$. Location of base (Table-IV; Fig: 8) of the sacral hiatus was maximum at the level of $5^{\text {th }}$ sacral vertebra (91.20\%) and there were a remarkable location of base of sacral hiatus at the level of coccyx $(8.10 \%)$.

Table- II

Shape of sacral hiatus

\begin{tabular}{lcc}
\hline Shape of sacral hiatus & No. & Percentage \\
\hline Inverted U & 65 & $38.00 \%$ \\
Inverted V & 60 & $35.10 \%$ \\
Irregular & 26 & $15.20 \%$ \\
Elongated & 10 & $5.80 \%$ \\
Dumbell & 9 & $5.30 \%$ \\
Bifid & 1 & $0.60 \%$ \\
\hline Total & 171 & $100 \%$ \\
\hline
\end{tabular}




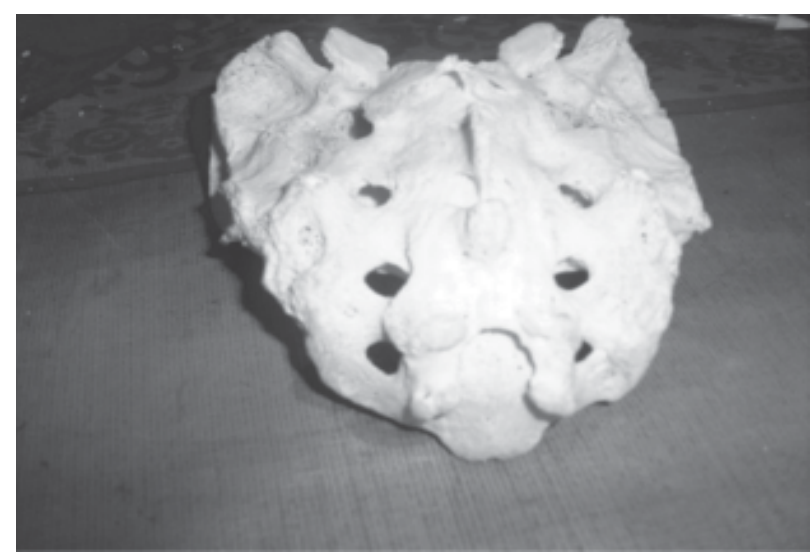

A. Inverted U shaped sacral hiatus

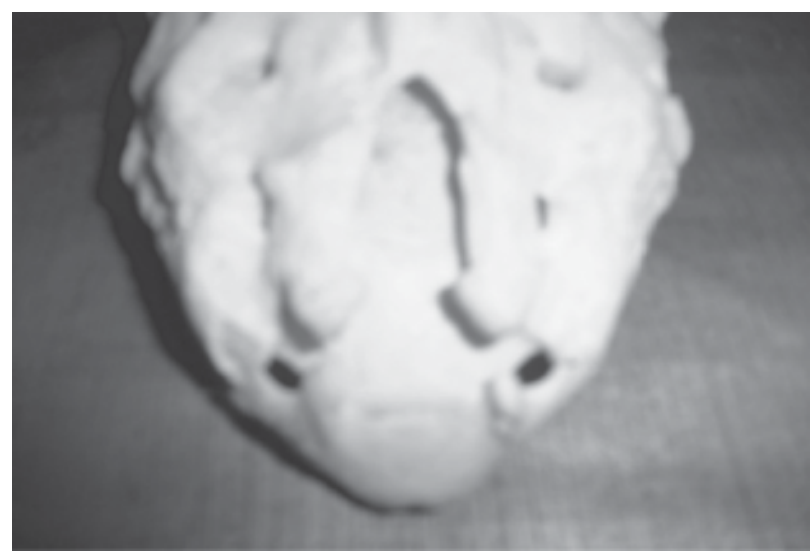

C. Inverted V shaped sacral hiatus

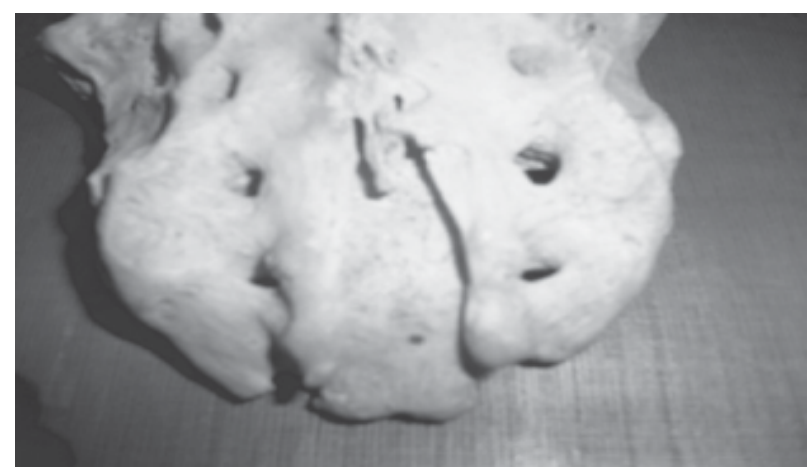

E. Irregular shaped sacral hiatus

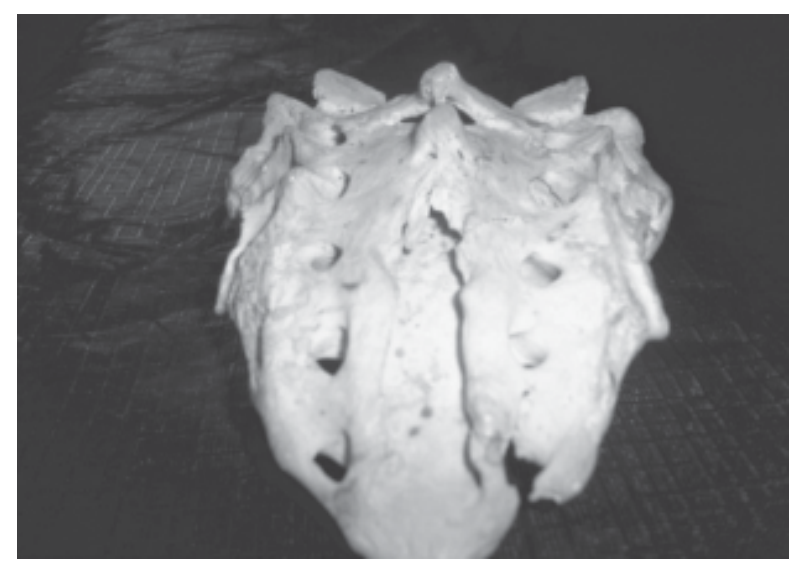

B. Elongated sacral hiatus

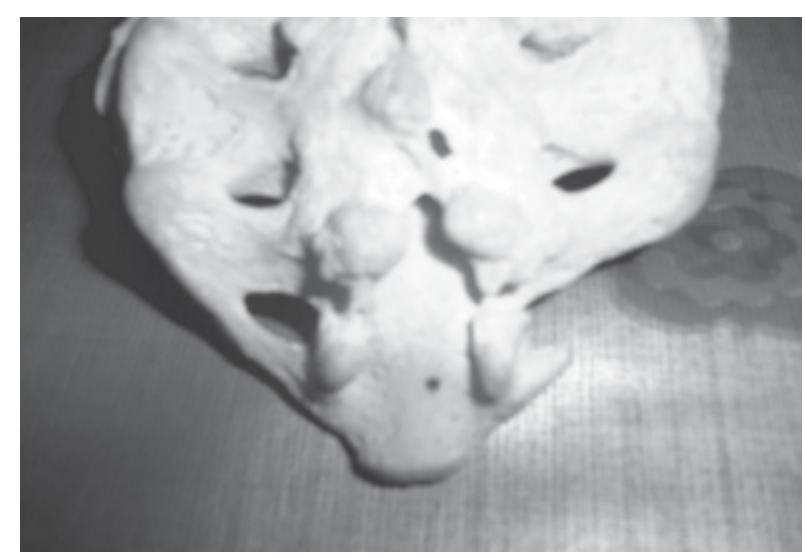

D. Dumbell shaped sacral hiatus

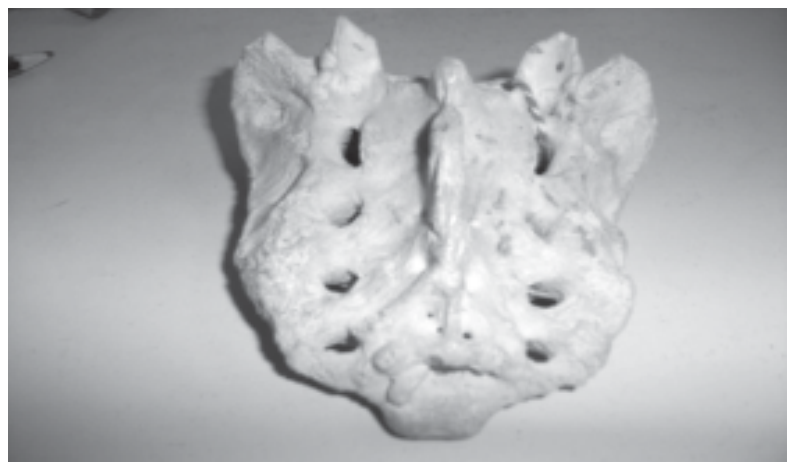

F. Bifid sacral hiatus

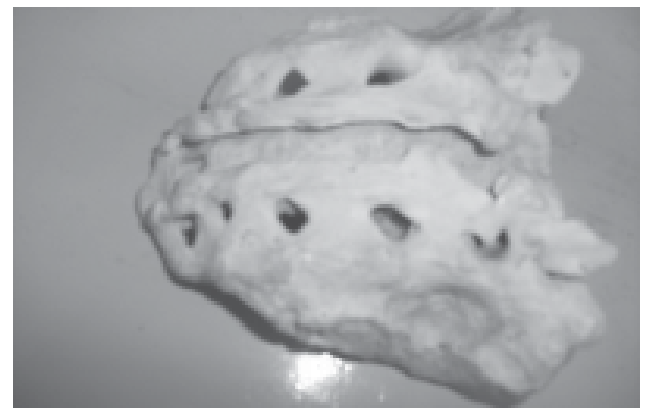

G. Agenesis of dorsal wall of sacral cana

Fig-6 : Different shapes of sacral hiatus ( $A, B, C, D, E, F, G)$ 
Table -III

Location of the apex of sacral hiatus in relation to the level of sacral vertebra $(n=171)$.

\begin{tabular}{lcc}
\hline Location of apex & No. & Percentage \\
\hline $4^{\text {th }}$ sacral vertebra & 103 & $60.20 \%$ \\
$3^{\text {rd }}$ sacral vertebra & 52 & $30.40 \%$ \\
$2^{\text {nd }}$ sacral vertebra & 8 & $4.70 \%$ \\
$5^{\text {th }}$ sacral vertebra & 8 & $4.70 \%$ \\
\hline Total & 171 & $100 \%$ \\
\hline
\end{tabular}

Table - IV

Location of the base of sacral hiatus in relation to the level of sacral/coccygeal vertebra $(n=171)$

\begin{tabular}{|c|c|c|}
\hline Location of base & No. & Percentage \\
\hline $5^{\text {th }}$ sacral vertebra & 156 & $91.20 \%$ \\
\hline $4^{\text {th }}$ sacral vertebra & 1 & $0.60 \%$ \\
\hline Coccyx & 14 & $8.20 \%$ \\
\hline Total & 171 & $100 \%$ \\
\hline
\end{tabular}

\section{Discussion:}

In the present study 172 (one hundred and seventy two) dried completely ossified grossly normal adult human sacra of both sexes (91 males and 81 females) were included. The mean length of sacral hiatus in male and female was found $26.38 \pm 12.02 \mathrm{~mm}$ and $25.63 \pm 10.46 \mathrm{~mm}$ respectively. Length of sacral hiatus was found greater in male than female and it was statistically significant $(\mathrm{P}<0.001)$. The mean anterior-posterior diameter of sacral hiatus at the apex found $4.76 \pm 1.73 \mathrm{~mm}$ in male and $4.92 \pm 2.13 \mathrm{~mm}$ in female. Transverse width of the sacral hiatus at the base found $17.29 \pm 3.89 \mathrm{~mm}$ in male and $18.01 \pm 3.70 \mathrm{~mm}$ in female. In both the measurement anteriorposterior diameter of sacral hiatus at the apex and transverse width of the sacral hiatus at the base found greater in female than male and it was statistically significant $(\mathrm{P}<0.001)$. Nagar ${ }^{3}$ observed that the mean length of sacral hiatus was $22.8 \mathrm{~mm}$. The mean anteroposterior diameter of sacral canal at the apex of sacral hiatus was $4.88 \mathrm{~mm}$. Narrowing of sacral canal at the apex of sacral hiatus, diameter less than $3 \mathrm{~mm}$, was observed to be significantly high, (15.6\%). The knowledge of anatomical variations of sacral hiatus is significant while administration of caudal epidural anesthesia and it may help to improve its success rate. The mean length of sacral hiatus was not similar to Nagar $^{3}$ but anteroposterior diameter of sacral canal at the apex of sacral hiatus was similar as the findings of Nagar ${ }^{3}$.

Regarding shape of the sacral hiatus, in the present study one sacrum had agenesis of sacral hiatus. So, out of 172 samples 171 sacra were studied for various parameters of sacral hiatus. Among them inverted U shaped was $38.86 \%$ and $37.05 \%$, inverted $\mathrm{V}$ shaped was $32.25 \%$ and $38.27 \%$, irregular shaped was $16.68 \%$ and $13.57 \%$, elongated shaped was $6.66 \%$ and $4.94 \%$, dumbell shaped was $5.55 \%$ and $4.94 \%$ and bifid shaped was $0.0 \%$ and $0.60 \%$ in male and female respectively. Different in shape of sacral hiatus between male and female found statistically not significant. Nagar $^{3}$ studied on 270 dry human sacra in Gujarat state to know the anatomical variations of sacral hiatus. Various shapes of sacral hiatus were observed which included inverted U (41.5\%), inverted V (27\%), irregular (14.1\%), dumbbell (13.3\%) and bifid (1.5\%). The findings of the present study was similar to Nagar $^{3}$. Location of apex of sacral hiatus was found highest in number at the level of $4^{\text {th }}$ sacral vertebra $(60.20 \%)$ and lowest in number at the level of $2^{\text {nd }}$ and $5^{\text {th }}$ sacral vertebra $(4.70 \%)$. Position of the apex of sacral hiatus at the level of $3^{\text {rd }}$ sacral vertebra was found $30.40 \%$. Nagar ${ }^{3}$ observed the apex of sacral hiatus was commonly found at the level of 4th sacral vertebra in $39.6 \%$. which was similar to present study. However, single bony landmark may not help in locating sacral hiatus because of anatomical variations. The knowledge of anatomical variations of sacral hiatus is significant in case of administration of caudal epidural anesthesia and it will improve its success rate.

\section{References :}

1. Newell RLM. Osteology. Standring S, et al. eds. Gray's anatomy: the anatomical basis of clinical practice. 40th ed. London: Churchill Livingston; 2008. p.724-28.

2. Peter LW, et al. eds. Gray's anatomy. 38th ed. London: Churchill Livingston; 2000. p.531-92. 
3. Nagar SK. A study of sacral hiatus in dry human sacra. J Anat Soc India 2004; 53(2): 18-21.

4. Snell RS. The Pelvis. In: Clinical anatomy by region. $8^{\text {th }}$ ed. USA: Lippincott Williams \& Wilkins: 2008. p.872-81.

5. Edwards WB, Hingson RA. Continuous caudal anaesthesia in obstetrics. Am J Surg 1942; 57 : 459-64.
6. Sekiguchi M, Yabuki S, Saton K, Kikuchi S. An anatomical study of the sacral hiatus: a basis for successful caudal epidural block. Clin J Pain 2004; 20(1): 51-4.

7. Singh R. Sacrum with five pairs of sacral foramina. Int $\mathrm{J}$ Anat Variations 2011; 4: 139-40.

8. Aggarwal A, Aggarwal A, Harjeet K, Sahni D. Morphometry of sacral hiatus and its clinical relevance in caudal epidural block. Surg Radiol Anat 2009; 31(10): 793-800. 